\title{
Sharia Banking Support to Help IT Start-Up Development in Bina Nusantara University
}

\author{
Gatot Hendro Prakosa'; Erwin Permana²; Hartanto ${ }^{3}$; Onggo Pramudito ${ }^{4}$ \\ ${ }^{1,2,3,4}$ Binus Entrepreneurship Center, Bina Nusantara University \\ Jln. Kebon Jeruk Raya No. 27, Jakarta Barat 11530, Indonesia \\ 'gprakosa@binus.edu; ${ }^{2}$ erwin.permana@binus.ac.id; ${ }^{3}$ hartanto@binus.ac.id; ${ }^{4}$ ong.latief@gmail.com
}

Received: $26^{\text {th }}$ February 2017/ Revised: $13^{\text {th }}$ June $2017 /$ Accepted: $28^{\text {th }}$ July 2017

How to Cite: Prakosa, G. H., Permana, E., Hartanto, \& Pramudito, O. (2017). Sharia Banking Support to Help IT Start-Up

Development in Bina Nusantara University. Binus Business Review, 8(2), 141-147.

http://dx.doi.org/10.21512/bbr.v8i2.2035

\begin{abstract}
This research was to find the possibilities of using the sharia banking method as the funding source alternatives for students or graduated students of IT start-up in Bina Nusantara University. This research was a qualitative research. In-depth Interview method was used to get the information. The researchers interviewed several informants that were considered as the competence individuals in Sharia Banking. It is found that sharia Banks are using the fatwa of Dewan Syariah Nasional (DSN - National Sharia Council) as their operational reference, that is included the fatwa on business funding. All informants agree that IT start-up has not been discussed by the DSN, and there is no any fatwa about it. However, IT start-up has been considered as the kind of business that cannot be funded by sharia banks due to the method of the business itself, which can be considered as gharar (a business that is forbidden in Islam).
\end{abstract}

Keywords: sharia banking, IT start-up, DSN

\section{INTRODUCTION}

Information Technology (IT) has been developed rapidly and dynamically. This development is also being followed by the development of IT-based businesses. It is not only about the development of the hardware, but also about the development of the software. The development of IT digital start-up (IT start-up) is the clear example of the development of IT-based businesses.

In Indonesia, the development of IT start-up has shown a significant growth. Freischald (2016) stated that funding for start-up in Indonesia had been increased significantly from billion Rupiahs (before 2014) to trillion Rupiahs (after 2014). In 2015, it also marked the huge funding received by the new e-commerce, Matahari Mall. The deal was worth of Rp6,92 trillion.

Based on the information from International Finance Corporation (Fabritz, Falck, \& Saavedra, 2016), the rank of Indonesia is 114 and remains far behind the ASEAN countries, such as Malaysia (18), Thailand (26), Vietnam (78), Filipina (95) and Brunei Darussalam (101). This condition is considered as the obstacle for entrepreneurship to grow including the IT start-up.

Moreover, the lack of initial capital is considered as the obstacles for entrepreneurship development. Future entrepreneurs failed to develop their business because they do not have sufficient fund. Thus, they choose to postpone or even cancel their desire to develop the business. This initial capital obstacle remains unsolved by considering that the bank supports are still unable to penetrate the new business players.

The Indonesian Central Bank, Bank Indonesia has stated that all banks in Indonesia should funnel at least $20 \%$ of total credit. The credits funneled to the Small and Medium-Sized Enterprises (SMEs) reached $19 \%$ of all total credits in 2014. Not all banks participated totally in it. One of the factors considered as the main cause of the reluctance of the banks is the 
high Non-Performing Loan (NPL) rate of the credits for the SMEs. Data from Bank Indonesia states that the SMEs are the top contributors to high NPL rate.

The high rate of NPL and the rigid banks' policies on loan return without considering the condition of the business have made the funneling credit rate to SMEs considerably low. Thus, it makes the creditors and the future creditors that want to start their business think twice before they submit the funding request.

Then, the sharia finance imposes a system that is well known as free from riba system (interest-free). This system has been considered as the solution for the most SMEs to get the funding. Thus, they can run, develop, or even to start their business. The Profit-Lost Sharing (PLS) is also the perfect solution to reduce the risk of the business owners.

The researchers find phenomena in the failure to grow IT start-up businesses, especially in the students of IT start-up. The main problem is their lack access to the funding resources. The number of Venture Capitals (VC) by far has been considered as the funding solution for IT start-up. It is because it can not cover the needs of funding, as the desire to start the IT start-up has increased significantly especially IT start-up students. This research is designed to determine the possibility of using the sharia banking method as the alternative funding sources for IT startup especially for the students or graduated students in Bina Nusantara University.

It has been known that the students and graduated students develop various kinds of potential IT startup business. However, it could not be developed because of the funding problems. The students and the graduated students are considered in the unbankable category. It means that they do not have access to any kinds of bank or financial institutions. On the other hand, the access to $\mathrm{VC}$ or personal investor is also similarly limited, compared to the potential IT startup. The involvement of sharia banks that impose the PLS scheme could be the solutions for the students and graduated students to develop their IT start-up idea. The potential of losing their assets can be minimized by using the PLS of the sharia banks. The PLS in the Sharia banking system would also give the chance banks to make a further penetration to the SMEs (Aida Kammoun \& Asma, 2013). In this research, the funding system of sharia banks is expected to reach the start-up business sector.

According to Ries (2011), start-up is a form of organization that specifically creates new thing in the very uncertain condition. Furthermore, Ries (2011) also stated that start-up was not limited to a group of well organized and professional organization, but it could also refer to individuals, that run the business from the garage of their house. Both kinds of organizations have the similar vision to penetrate the uncertainty in finding their way to form the sustainable business. Meanwhile, Neil Blumenthal in (Robehmed, 2013) suggested that start-up was an organization or company that worked to solve problem, where the solution was completely unclear, and there was no guarantee of success at all.

There are no rigid rules of how start-up is defined, or what distinguish the start-up and the 'conventional' business in term of revenue, profit and workers are (Robehmed, 2013). However, the experts agree that start-up is a company that is designed to grow rapidly. The company only focuses on the growth that is not limited by region. This is different from start-up and small business as explained by Paul Graham in Robehmed (2013).

Only small numbers of capital issues of startup can be covered by VC and Angel Investor (AI). Though it can be considered as a solution, the limited number of $\mathrm{VC}$ and $\mathrm{AI}$ has become the gigantic problem hampering the start-up to grow. It is because the number of start-up receiving the investment is very limited. Samila and Sorenson (2011) found that the existence of $\mathrm{VC}$ had significant impact on the start-up growth. Furthermore, based on the research result, some evidences were found that $\mathrm{VC}$ affected the number of the start-up, workers, and income positively.

Information technology has been considered as the characteristic of Bina Nusantara University. Thousands of IT graduates scattered all over Indonesia is the proof of the quality of IT graduates. These potentials are still increased by developing more specific study programs such as Computer Science and Information System. Thus, the rapid growth of IT and the IT-related business have become the opportunity to all students and graduates in Bina Nusantara University to develop their desire by developing IT Start-Up. The students and graduates develop various kinds of applications. Those applications can be developed furthermore to be IT Start-Up. The only major problem is that the students and the graduates have very limited access to $\mathrm{VC}$ or AI. The existing VC and AI cannot cover the whole potential IT start-up.

Islam sees the trading (business) as the biggest income source for human kind. One of the most wellknown hadith of the Prophet, Muhammad (PBUH) states "nine of ten doors of fortune is trading." Furthermore, Islam has clear and detail rules about how a business should be done. Zainal, Antonio, and Hadad (2014) described the basic business principles of Islam. The basic business principles in Islam covered honesty, fairness, openness, and togetherness. Meanwhile, the objective of business was resulted target, material and non-material, growth, sustainability, and blessing. Islam uses the free from riba concept. Islam forbids all riba practices. According to the Sharia finance, riba has several negative impacts on the economy (Ismail, 2011). First, inflation is the interest component added to the cost component. It will affect the price of the goods. Second, economic dependence means the borrowers will always have to pay the interest to the money lenders on installment basis. Hence, the sharia finance only allows PLS or nisbah. In the conventional banking system, interest is being stated at the beginning of the deal regardless the business could be profitable or not. Thus, the lenders, no matter how the business 
goes, will get benefits. In the PLS system, the lenders and the borrowers have an agreement about the nisbah ratio allowing both sides to have profits or losses.

Similarly, Ismail (2011) also stated that in the conventional banking system, the amount of the interest was calculated based on the interest percentage multiplied by the amount of the loan. On the other hand, nisbah ratio was calculated based on the agreement between the involved parties. Then, the amount of the received interest would remain the same in the conventional banking system regardless the condition of the business. However, sharia system applies different method. The amount of the PLS (nisbah) is different from time to time based on the condition of the business. Hence, sharia banking is different system than the conventional banking system. Sharia banking system does not apply the interest system, but it has nisbah system, which is allowed by Islam.

Ismail (2011) also divided the differences between Sharia banking system and conventional banking system in several categories. First, in investment, the Sharia banks are only allowed to funnel their funds to halal investment such as in product or process. Second, in return, it is given in the form of nisbah. It should be fairly calculated, Third, the agreement should be based on Islamic rules. Fourth, the investment orientation should not only be based on profit orientation, but it should also consider other aspects such as social aspect. Last, for dispute resolution, it should be done under the agreement of both sides. If it hits the dead end, it should be continued in the religious court.

Moreover, in sharia banking system, funding is considered as a form of investment of the sharia bank to the business owner. There are several famous akad (methods) in sharia banking systems related to investment. Two of the most famous are mudharabah and musyarakah. Akad mudharabah is a funding where shahibul Maal (the funders) give the fund and let the mudharib (borrowers) manage the business entirely. The agreement should be completed with the deal of PLS with the compromised and agreed portion of each party (Ismail, 2011; Zainal et al., 2014). The loss caused by incapability of the borrowers is borrowers' responsibility. The loss is entirely the lenders' responsibility if the borrowers can prove that the business has been managed as it is supposed to be. Meanwhile, Akad musyarakah is business fundings where two or more parties agree to collect some fund to form a join-business with the compromised capital and profit portion. In term of loss, it would be everyone's responsibility (Ismail, 2011; Zainal et al., 2014).

Askari, Iqbal, and Mirakhor (2015) stated that Islamic Banking had several funding schemes such as murabahah (value-added trading based on agreement of both parties), ijarah (leasing), mudarobah (investment cooperation), musyarakah (PLS), bay' mu'ajjal and bay'salam (sales contract).

Beik, Ayyuniyyah, and Arsyanti (2014) found that most SMEs in Indonesia had problems in accessing the funding included in the banks. The assumptions of the banking industries to the SMEs also have impacts on the funding access as well. Meanwhile, Islam et al. (2014) suggested that SMEs were not the most interesting sector for the conventional bank industries. It was considered as the expensive sector for the banks. Moreover, the inexistence of collaterals is also the factor that stops the students to get access to banks (Busnety \& Tambunan, 2013). To start the business, due to the impossibility to get the loan, SMEs tend to use their savings or other loans. It can be from the informal institutions, which have higher risks for the business owners and higher interest rate.

Sharia finance systems are based on two main jurisdiction references in Islam, Al-Quran and Al-Hadith. Both forbid riba (interest), gharar (uncertain contract), qimar/maysir (gambling), and all investments which is forbidden in Islam (the investment would be considered haram) (Ahmed \& Grais, 2015; Ismal, 2013; Kureshi \& Hayat, 2015; Samareh, 2013).

Askari et al. (2015) also agreed that the based idea of sharia finance was the disallowance of riba and the alternative versions. It was stated that in sharia finance, the goods should be real. Then, money would only be treated as the "potential" capital that only had values after being combined with the other resources to do the productive activities. Money could not act by itself.

According to Ahmed and Grais (2015), there are several operational ways in the sharia finance that should be based on several basic characters. Those are the disallowance of flat interest rate payment, unsecured deposit investment without profit guarantee, risk sharing, and real material inside the transaction. Theoretically, both Islamic banks and conventional banks have huge difference in the obligation and risk. However, in practices, the Islamic banks avoid the risksharing $\neg$ and choose to use the loan-contract scheme. Thus, practically it has no different with the loan scheme of conventional bank, where the borrowers should only pay the amount of money regardless the condition of the business (Rahman et al., 2013). Then, Pepinsky (2013) explained that the players in the sharia banking industry in Indonesia were the part of the conventional banks. This indicated that the sharia principles had not been entirely applied in the sharia banking industry.

Oseni, Hassan, and Matri (2013) said that in France, sharia banking had been considered as the credible alternative for SMEs. While, in Germany, the integration of sharia finance system to their economic system was ongoing. It is a prove that sharia finance is accepted in many countries which are not the Islamic countries. It is a very interesting system for some countries, such as in the country which is not an Islamic country, or Moslem as the majority (Aida \& Imen, 2014).

For business owners, sharia finance is the solution. Gunputh (2014) concluded that sharia finance had simpler procedure in term of getting the 
fund compared to the conventional banking industry. That is the reason why it might be useful for the young entrepreneurs or for those who wanted to start their own IT start-up. As long as the execution is perfectly done, the Islamic micro-funding is useful to reform the social-economic condition. Then, it will develop the autonomy culture financially or operationally.

Dewan Syariah Nasional (DSN - National Sharia Council) is a council formed as the platform to accommodate the Muslim in economic matters, and boost the execution of economic system based on Islamic rules. DSN was initiated in 1997. It was based on the recommendation of the Sharia Mutual Funds workshop held by MUI. DSN is officially formed on February $10^{\text {th }}, 1999$ based on SK MUI number Kep-754/MUI/II/1999 about the Formation of DSN. Moreover, DSN is obligated to release all fatwa about sharia finance used as the basic reference for sharia finance institutions. The fatwa released by DSN is used as the foundation of sharia finance operation rules in the Indonesian Central Bank, Bank Indonesia. Then, DSN has to supervise all sharia finance activities and access it so that it can refer to the Islamic rules. This supervision activity is done by Dewan Pengawas Syariah (DPS - Sharia Supervisory Council) (Umam, 2012; DSNMUI, 2013).

The main function of DPS is to supervise banks' activities and ensure the activities will remain in the Islamic way. DPS is fully responsible for the offered products or services of the banks, so those can be compatible with the sharia principles (Nur, 2008). Moreover, according to Faozan (2013), the role of DPS is to direct, give thoughts and suggestions to the sharia banks' directors related to the sharia aspect, review and access the banks in the execution of the DSN's fatwa. DSN also supervises the fatwa implementation on the operation of the sharia banks, actively or passively.

\section{METHODS}

This is a qualitative research using the in-depth interview. It is the most comprehensive method to gain the qualitative data and can be used for various purposes, such as problem identification, assessment, or strategic planning (Guion et al., 2006). An in-depth interview is useful to obtain the detail information like opinion from the expert or to explore some new issues comprehensively. It gives the researchers the chance to get the complete descriptions about the researched issues (Boyce \& Neale, 2006). To ensure that the interview is successful, the researchers have to feel the condition of the people interviewed, and be more flexible on some certain things during the interview (Berry, 1999).

The most important part of the in-depth interview is the sampling phase. According to Cresswell cited by Turner (2010), the researchers should use one of the strategies to get the perfect quality of informant who can give the relevant information. Then, this research uses the purposive sampling method. It is to gain all necessary information related to the sharia banking as the funding source for the IT start-up for the students and graduated students in Bina Nusantara University. The candidates are selected from several high-profile sharia banks in Indonesia. The interview will be stopped after the researchers have found the consistent facts of the topic.

Moreover, the collected data are arranged systematically. The researchers will organize the data into several categories, describe it into units, synthesize, arrange in pattern, choose and assemble the conclusion. The five categories of the information, are DSN's fatwa, DPS policies, company cash flow, maximum lending point, and good-will transaction.

Referring to Guion et al. (2006), the process after interview is transcribing, analyzing, and analyzing. The data analysis of this research uses the coding method of Corbin and Strauss (1990) which is also cited by Sekaran and Bougie (2013). These are three coding process in this research, namely open coding, axial coding, and selective coding. Then, it also applies validity test. According to Patton in Moleong (2013), one of the validity tests in the qualitative research is the triangulation method. The triangulation method consists of four ways. Those are source triangulation, method triangulation, researcher triangulation, and theoretical triangulation. The researchers choose to use the researcher triangulation.

\section{RESULTS AND DISCUSSIONS}

This research starts from obtaining informants from several sharia banks in Indonesia. The informants are the individuals that have been in the industries for at least five years and understand the term of the interview. To confirm that the informants have enough knowledge about the IT start-up, the researchers have conducted the preliminary interview. The interviews focus on the informants' knowledge about IT start-up.

This research involves seven informants from two sharia banks. The informants speak as the practitioners in sharia banking industries. Informants' ages range from 35 to 42 years old. Three informants are from business development department, two informants are the marketing division, and the other two informants are in the funding divisions. The data of the informants can be seen in Table 1 .

Table 1 Informants Data

\begin{tabular}{ccccc}
\hline No & Informant & $\begin{array}{c}\text { Educational } \\
\text { Backgrounds }\end{array}$ & $\begin{array}{c}\text { Division/ } \\
\text { Department }\end{array}$ & Age \\
\hline 1 & A & IT & Business Dev & 35 \\
2 & B & IT & Business Dev & 38 \\
3 & C & $\begin{array}{c}\text { Information } \\
\text { System }\end{array}$ & Business Dev & 40 \\
& & Economic & Marketing & 36 \\
4 & D & Business & Marketing & 38 \\
5 & E & Economic & Funding & 45 \\
6 & F & Economic & Funding & 41 \\
7 & G & & & \\
\hline
\end{tabular}


The informants show excellent comprehension about IT start-up. The informants stated that IT startup is a business that is rapidly developing at the moment. They also agree that it will be developed for at least another decade. As users, all informants state that the development of IT start-up have given them more solutions of what they need in daily life. It gives them simple ways to access many things. Moreover, the rapid development of the IT start-up industry has created strict competition between one IT startup business with the others. In the end, it will finish on the basic factor to gain customers, and the price competition. For the informants as users, it will be beneficial for them.

Based on the interview result, the researchers divided the information based on five categories. Those are DSN's fatwa, DPS policies, company cash flow, maximum lending limit, and good will transaction. First, all informants agree that all the operational policies of the sharia banking in Indonesia should be based the fatwa of DSN. According to Otoritas Jasa Keuangan (OJK - Finance Service Authority) (2014), the sharia finance business should be based the sharia principles including the fatwa that is issued by the DSN of Majelis Ulama Indonesia (MUI). Relating to the IT start-up and the funding for business maintenance, both lenders and investors agree that as long as there is no clear fatwa of DSN that forbids the activities, the sharia banks do not have the reasons for not giving the fundings to the IT start-up. Certainly, all terms and conditions are applied.

Second, one of the organizations in the sharia banks is the DPS. DPS is the center of the banks' operational policies. The decision made by DPS is used as the basic reference of all sharia bank's operational policies. DPS makes the decision based on various considerations like business. However, the policies made by DPS should not be against the DSN's fatwa. Meanwhile, in the conventional bank, the sharia banks are also regulated by all regulations from Bank Indonesia. Sharia banks should do their operations based on the regulations and the DSN's fatwa.

Third, it is the cash flow. If the cash flow of one party is not healthy, it may have impacts on the other parties. In general, it affects the ability of the borrowers to pay the loans to the bank. According to the informants, the most 'mainstream' of IT start-up does not have the healthy cash flow or negative cash flow. Based on that, they agree that the newly formed IT start-up will have the similar conditions as well. In IT start-up, people still put their efforts on business development by doing massive promotion campaign. By doing this, they have to spend a large amount of money. However, all informants believe that the transactions made by the IT start-up are not sufficient to cover the operating cost.

It means the IT start-up does not have the ability to pay the loans given by the banks. According to the informants, the main idea of IT start-up is to develop the image of the business by improving the numbers of users. After the business has been developed shown by the improvement of the numbers of users, the IT start-up can search for other bigger investor. The new investor will make a bigger investment used by the IT start-up to return the investment and agreed benefits and to develop the image of the business more.

Fourth, all informants also agree that in business funding, sharia banks are limited by regulations from Bank Indonesia about the maximum lending limit. Based on the Letter of Bank Indonesia Number 7/14/DPNP year 2005, it stated that in funding, circumspection principles and risk management in the form of maximum lending limit were applied. This letter also explained about how the bank should decide the counterparty related to sharing ownership, management, and finance between related parties and group of borrowers (Bank Indonesia, 2005). Bank are only allowed to lend about $25 \%$ of the total capital in the banks. In this context, informants state that as long as the funding for the IT start-up is less than $25 \%$ of the total capital, technically, the funding can be granted.

Fifth, the term "goodwill" is from the informant. Some informants agree that the IT startup as the goodwill transaction. It is identical with the transactions of intellectual matters or patent. It does not have the physical existence of the funding objects. Furthermore, the other informants state that the IT start-up can not be considered as equal with patent transaction or intellectual matters transactions. IT start-up is closer to gharar transaction, which is prohibited and considered as haram in Islam.

Ismal (2013), Kureshi and Hayat (2015), Samareh (2013) agreed that gharar was included in the haram-classified transaction, as well as riba and speculation. Furthermore, sharia banks as financing institution should be free of riba, gharar, and speculation in its operations. Samareh (2013) also added that gharar was defined as a transaction with high risk, and contained uncertainty. However, uncertainty is the part of IT start-up. According to Tarmizi (2016), gharar is a transaction that has no end. Both involved parties can not define when it ends. Gharar is also considered as the transaction that contains speculations. Similarly, Ismal (2013) suggested that gharar involves the uncertain condition on the transactions. Gharar in IT start-up can be considered in gharar on the object. Tarmizi (2016) stated that this type of gharar happened when both of the parties involved in the transaction did not know exactly how the transaction would be done in the future.

Moreover, rules number 31/POJK.05/2015 from Otoritas Jasa Keuangan (OJK - Finance Service Authority) about operational of sharia funding stated that the sharia funding should be able to fulfill the fair, balance, beneficial, and universality principles. It shoud not contain gharar, maysir, riba, zhulm, risywah, and haram objects (Otoritas Jasa Keuangan, 2014). 


\section{CONCLUSIONS}

There are several conclusions in the research. First, DSN as the highest reference on the operation of the sharia banking industry has not released any kinds of fatwa related to the IT Start-Up. Second, DPS in each bank still agrees that as long as there is no fatwa from DSN, funding for IT start-up is allowed. Third, the cash flow for IT start-up is negative. By seeing that point, and referring it to the rules from Bank Indonesia in banking risk management, IT start-up business is considered as the high-risk business. Fourth, maximum lending limit stated by Bank Indonesia is up to $25 \%$ of the total capital of the bank. The limit is applies to the IT start-up. Fifth, IT start-up is categorized as gharar. It can be concluded that this type of business can not be funded by sharia banks because it is against the basic rules of sharia banks which are prohibiting riba, gharar, maysir, and speculation.

Summing up the conclusions, and answering the objective of the research, IT start-up is not one of the businesses that cannot have the sharia funding method. The fact that it is considered as gharar is the main consideration of why it cannot be funded by the sharia banks. However, it can happen in the future, if DSN as the highest reference in sharia banking industry in Indonesia releases a fatwa stating otherwise.

\section{REFERENCES}

Ahmed, A. M. E. T, \& Grais, W. (2015). Islamic finance and economic developments: Risk management, regulation and corporate governance. New Jersey: John Wiley \& Sons.

Aida, K., \& Imen, K. (2014). Islamic finance for future entrepreneurs: Exploring Tunisian business students' knowledge and potential usage of Islamic financing products. Journal of Emerging Economies and Islamic Research, 2(3), 1-14.

Aida Kammoun, A., \& Asma, A. (2013). The effect of the subprime crisis on the financing of entrepreneurial activities by Islamic banks. Review of Economics \& Finance, 3, 77-90.

Askari, H., Iqbal, Z., \& Mirakhor, A. (2015). Introduction to Islamic economics: Theory and application. Singapore: John Wiley \& Sons.

Beik, I. S., Ayyuniyyah, Q., \& Arsyanti, L. D. (2014). The role of Islamic rural bank in financing the SMEs: Customer perspective analysis (case study of Amanah Ummah bank in Bogor City, Indonesia). Tazkia Islamic Finance and Business Review, 4(2), 741-759.

Berry, R. S. Y. (1999). Collecting data by in depth interviewing. In British Education Association Annual Conference, University of Sussex September 2-5-1999.

Bank Indonesia. (2005). Surat edaran kepada semua bank umum di Indonesia. Jakarta: Bank Indonesia.

Boyce, C., \& Neale, P. (2006). Conducting in-depth interviews: A guide for designing and conducting indepth interviews. Evaluation, 2(May), 1-16. http:// doi.org/10.1080/14616730210154225

Busnety, I., \& Tambunan, T. T. H. (2013). Development of small and medium enterprises and their access to finance: The story from Indonesia. In $2^{\text {nd }}$ IBSM International Conference on Business and Management, (October).

Corbin, J. M., \& Strauss, A. (1990). Grounded theory research: Procedures, canons, and evaluative criteria. Qualitative Sociology, 13(1), 3-21. http:// doi.org/10.1007/BF00988593

DSNMUI. (2013). Sekilas tentang DSN MUI. Retrieved January $25^{\text {th }}, 2017$ from https://dsnmui.or.id/kami/ sekilas/

Fabritz, N., Falck, O., \& Saavedra, J. C. (2016). Doing business 2015. CESifo Forum (Vol. 17). Washington DC: The World Bank.

Faozan, A. (2014). Implementasi Good Corporate Governance dan peran dewan pengawas Sharia di bank Sharia. La Riba, 7(1), 1-14.

Freischald, N. (2016). Ulasan 5 tahun pendanaan startup di Indonesia sejak 2011. Retrieved from https:// id.techinasia.com/ulasan-5-tahun-pertumbuhanpendanaan-emstartupem-di-indonesia-sejak-2011

Guion, L. A., Diehl, D. C., McDonald, D. (2006). Conducting an in-depth interview. Retrieved from http://greenmedicine.ie/school/images/Library/ Conducting\%20An\%20In\%20Depth\%20Interview. pdf

Gunputh, R. P. (2014). Micro-credit in conventional banking: Would Islamic banking be the golden age for entrepreneurs? the Mauritius case study. Journal of Social and Development Sciences, 5(1), 14-25.

Islam, M. A., Yousuf, S., \& Rahman, M. I. (2014). SME financing in Bangladesh: A comparative analysis of conventional and Islamic banks. Journal of Islamic Banking and Finance, 2(1), 79-92.

Ismail. (2011). Perbankan sharia. Jakarta: Kencana Prenamedia.

Ismal, R. (2013). Islamic banking in Indonesia - new perspectives on monetary and financial issues. Singapore: John Wiley \& Sons.

Kureshi, H., \& Hayat, M. (2015). Contracts and deals in Islamic Finance - a user's guide to cash flows, balance sheets, and capital structures. Singapore: John Wiley \& Sons.

Moleong, L. J. (2013). Metode penelitian kualitatif(Revisi). Bandung: ROSDA.

Nur, H. M. (2008). Dewan pengawas sharia dalam sistem hukum perbankan: Studi tentang pengawasan bank berlandaskan pada prinsip - prinsip Islam. Lex Jurnalica, 6(1), 1-15.

Oseni, U. a, Hassan, M. K., \& Matri, D. (2013). An Islamic finance model for the small and medium-sized enterprises in France, JKAU: Islamic Econ., 26(2), 151-179.

Otoritas Jasa Keuangan. (2014). Peraturan Otoritas Jasa Keuangan Nomor 31/POJK.05/2014 tentang penyelenggaraan usaha pembiayaan syariah. Jakarta.

Pepinsky, T. B. (2013). Development, social change, and Islamic finance in contemporary Indonesia. World Development, 41(1), 157-167. http://doi. 
org/10.1016/j.worlddev.2012.06.007

Rahman, R. A., Muhammad, A. D., \& Mahayudin, I. (2013). Applicability of the Islamic Micro-Investment Model (IMIM) in Islamic bank in Malaysia. World Applied Sciences Journal, 24(5), 609-616. http://doi. org/10.5829/idosi.wasj.2013.24.05.13213

Ries, E. (2011). The lean startup: How today's entrepreneurs use continuous innovation to create radically successful businesses. Crown Business.

Robehmed, N. (2013). What is a startup? Retrieved from https:/www.forbes.com/sites/ natalierobehmed/2013/12/16/what-is-astartup/\#5bfff92c4044

Samareh, C. (2013). Contemporary Islamic finance innovations, applications and best practices. New Jersey: John Wiley \& Sons.

Samila, S., \& Sorenson, O. (2011). Venture capital, entrepreneurship, and economic growth. Review of
Economics and Statistics, 93(1), 338-349. http://doi. org/10.1162/REST_a_00066

Sekaran, U., \& Bougie, R. (2013). Research method for business. Chennai, India: John Wiley \& Sons.

Tarmizi, E. (2016). Harta haram - muamalat kontemporer. Bogor: PT Berkat Mulia Insani.

Turner, D. W. (2010). Qualitative interview design: A practical guide for novice investigators. The Qualitative Report, 15(3), 754-760. http://doi.org/ http://www.nova.edu/ssss/QR/QR15-3/qid.pdf

Umam, K. (2012). Legislasi fikih ekonomi perbankan: Sinkronisasi peran Dewan Sharia Nasional dan komite perbankan Sharia. Mimbar Hukum, 24(2), 357-375.

Zainal, V. R., Antonio, M. S., \& Hadad, M. D. (2014). Islamic business management: Praktik manajemen bisnis yang sesuai dengan Syariat Islami. Yogyakarta: BPFE. 